\title{
UK substance use policy research should think local
}

This is the accepted version of an article which has now been published in Drugs \& Alcohol Today and is available here: http://www.emeraldinsight.com/doi/abs/10.1108/DAT-02-2015-0006

This article is (@ Emerald Group Publishing and permission has been granted for this version to appear here (http://eprints.bournemouth.ac.uk/). Emerald does not grant permission for this article to be further copied/distributed or hosted elsewhere without the express permission from Emerald Group Publishing Limited. See more at: http://www.emeraldgrouppublishing.com/authors/writing/author rights.htm\#sthash.Vhl4bBWf.dpuf

\section{Author Details}

Name: William Haydock

Role: Visiting Fellow

Department: Faculty of Health and Social Sciences

University/Institution: Bournemouth University

Town/City: Bournemouth

Country: UK

Corresponding author: William Haydock

Corresponding Author's Email: whaydock@bournemouth.ac.uk

Acknowledgments (if applicable):

This paper was not supported by any funding agency in the public, commercial, or not-for-profit sectors. An earlier version of this paper was presented at the "New Problems, Old Solutions?" conference at the University of Leeds in December 2014. I am grateful to the comments and advice of those who attended, as well as the two anonymous referees.

Biographical Details (if applicable):

Dr William Haydock is a Visiting Fellow at Bournemouth University and the Health Programme Advisor for substance misuse policy and commissioning within Public Health Dorset. He has published academic articles on the UK night-time economy and alcohol policy more broadly in a range of journals, blogs at http://thinking-tosome-purpose.blogspot.co.uk and tweets @WilliamHaydock

\section{Structured Abstract:}

Purpose (mandatory)

This paper considers how policy researchers should respond to recent developments in substance use and the governance of drug and alcohol policy in the UK.

Design/methodology/approach (mandatory)

The paper takes two elements from the 2010 UK Drug Strategy -supply and treatment -and considers a case study in each to briefly examine the potential role of local policymakers in shaping how substance use is experienced.

\section{Findings (mandatory)}

It is argued that the Coalition Government's health reforms have given local commissioners greater autonomy over treatment policy than they had under the preceding Labour Government. Similarly, the regulation of new psychoactive substances in the UK has left local areas to determine their own approach to controlling supply through retail outlets.

\section{Research limitations/implications (if applicable)}

Drawing on the broader academic literature on policymaking, this paper calls for ethnographic research into local policymaking related to substance use, which will help to illuminate how perceived policy problems are shaped by particular local systems and understandings of evidence.

Originality/value (mandatory)

While this paper is not unique in identifying the importance of locally-based research, it identifies the particular relevance of this research agenda in the UK today. It seeks to inform and encourage research that can shape the development of local policymaking.

\section{Keywords:}

Alcohol policy, drug policy, localism, methodology, new psychoactive substances, public health

\section{Article Classification:}

Viewpoint 


\section{UK substance use policy research should think local}

\section{Introduction}

Many discussions of 'alcohol policy' or 'drug policy' approach issues with a national or international perspective. Alcohol policy is often considered at a national level, with studies of the UK generally taking as their unit of analysis either Britain (Greenaway, 2003; Thom, 1999; Yeomans, 2014) or England (Nicholls, 2009). Drug policy analyses tend to take a more international focus (e.g. Berridge, 2013), though there are certainly examples of analysing particular countries' approaches (Duke, 2013).

There are good reasons behind these units of analysis: key aspects of policy are certainly worked out at national and international levels, with national government strategies in place in the UK for both alcohol (HM Government, 2012) and drugs (HM Government, 2010), and agreements on the trade in various substances set by bodies such as the UN (e.g. United Nations, 1988) and the EU (The Herald, 2014). Robin Room (2004) even suggested that the UK Labour Government in 2004 'intended to eviscerate any possibility of effective action on alcohol issues at the local level'.

However, it is argued in this article that there may be an opportunity for research to consider the policymaking process at a local level. Some of the most interesting substance use policy developments in recent years have come at a federal or devolved level, with states in the USA legalising marijuana use (Lee, 2014), and Scotland taking a different path in the regulation of alcohol from other areas of the UK (Katikireddi et al., 2014; Mahon and Nicholls, 2014). I suggest in this article that recent developments in the UK have increased the relevance of the local element of policy. Actors that not been traditionally closely involved in substance use policy - such as local authority trading standards teams - have become crucial players in this process. Such local actors of course remain significantly constrained by national and international policy, but have a greater role than previously that is underexplored by policy researchers.

Where local substance use policy is considered, it tends to describe policies that are in place and perhaps assess their effectiveness (e.g. Holder and Reynolds, 1997; Holmila and Warpenius, 2007; Mawby, 2012). This article instead calls not for an analysis of the policies themselves, but of the process that produced them. Both research questions have their place. While it is important to know whether a policy 'works', if it is to be established it is essential to understand how the decisions are made that put a particular initiative in place.

In addressing how substance use policy is local, this article considers two key elements from the 2010 UK Drug Strategy (HM Government, 2010): supply and treatment. Each element is considered with a dedicated but brief case study: the public health reforms in relation to treatment, and the emergence of new psychoactive substances in relation to supply. Definitive research evidence is presented in neither instance to make a particular case regarding a general direction of travel or within a specific local area. The article, rather, is a call for research to investigate how local policy is played out, to generate precisely this kind of evidence.

By focusing on supply and treatment, the article neglects the third element identified in the 2010 Strategy: demand. This absence could be justified on the basis that it can be problematic to 
separate an analysis of demand from supply - the demand for mephedrone can be seen as shaped by the supply of ecstasy and cocaine (McElrath and Van Hout, 2011) - but nevertheless policy on preventive work that might shape future demand is not considered in the same detail here. In some senses this might be an area of substance use policy moving in the opposite direction. The development of academy status for schools limits the control local authorities can exert, and, as recently suggested by the House of Commons Education Committee, personal, social, health and economic (PSHE) education may develop statutory status, bringing it under more centralised control (House of Commons Education Committee, 2015). The topic of prevention, then, deserves separate and fuller consideration.

Although this article focuses on policy surrounding the use of substances other than alcohol, in many respects the same arguments and claims could - and should - be made with respect to alcohol. At the same time, there is a richer seam of locally-rooted work on alcohol policy, not least because so much regulation of alcohol has been locally exercised - for example licensing of retail through magistrates and now local authorities.

The article focuses on the case of the UK, and most specifically England, as this is where the public health reforms discussed have taken place and where the relevance of local agencies has notably increased since Room's (2004) article on the national alcohol strategy. (In fact, based on the work of Humphreys and Eisner (2010), it is unclear whether the planned evisceration of local action perceived by Room even proved possible.) Research of the kind I call for has been undertaken elsewhere, for example in New Zealand (Maclennan et al., 2013) - and I am not alone in identifying its importance in England. Most recently, the London School of Hygiene and Tropical Medicine hosted a seminar considering how local and national alcohol policy interact, with considerable discussion of historical and well as current debates (MacGregor, 2014). Similarly, the work of Phillips and Green (2015) hints at further insights on the workings of local government in relation to public health - and alcohol policy specifically. I can only hope that this article will encourage similar work.

\section{Treatment: from the National Treatment Agency to local public health}

2001 was a key year in the recent history of substance misuse policy in the UK. At this point, the National Treatment Agency (NTA) was created to oversee drug treatment in England and policy came under the aegis of the Home Office (Shapiro, 2013). The NTA provided funding for the commissioning of treatment services, governed through partnerships of relevant agencies including Primary Care Trusts (PCTs), Police, Probation and local authorities. Along with this funding came very clear guidelines on practice, performance management frameworks and effectively payment by results for local commissioning teams. Commissioners across England, in managing providers, largely used the same data provided through the National Drug Treatment Monitoring System (NDTMS), undertook the same needs assessment and planning processes as set out by the NTA, and were allocated funding based on a formula to include activity and performance of the local treatment system (National Treatment Agency, 2013).

This central direction entailed the wide influence of a particular philosophical and political understanding of substance use and treatment. The starting point, perhaps unsurprisingly given the location of responsibility within the Home Office, was the New Labour philosophy of being 'tough on the causes of crime'. This emphasis and its continuity are well illustrated by the NTA and subsequently PHE presentations designed to answer the question 'Why Invest?' in substance misuse 
treatment. The 2012 version stated that 'the overall cost of drug addiction is huge' but illustrated this with distinctly different figures for costs related to health and crime (National Treatment Agency, 2012). The annual cost of drug-related crime was noted to be $f 13.9 \mathrm{bn}$, while the cost to the NHS of drug misuse was cited as $f 488 \mathrm{~m}$, a mere $3.5 \%$ of the crime figure.

This approach of centrally controlling funding and governance of drug treatment is no more. From 2013 , local allocations for substance misuse treatment have simply been absorbed into public health budgets now handed over to local authorities, and do not reflect recent activity or performance of the treatment system. While NDTMS remains, the functions of the NTA have been absorbed into Public Health England (PHE), but without the influence that comes with holding and distributing budgets. Needs assessment and treatment planning process, as well as broader governance arrangements, are subject to the decisions of local policymakers.

This shift to local control within public health budgets may herald a change in approach, as public health is typically based on 'population health' (Faculty of Public Health, 2010), rather than the intensive targeting of opiate and crack users characteristic of the crime-oriented approach of the NTA. However, a more health-oriented approach to substance use should not be seen as inevitable. As Judith Green (2014) has noted, the shift of public health responsibilities (and funding) to local authorities has concerned some in the profession, and decision-makers will need to balance a number of competing aims and agendas in determining local policy. The shift in governance arrangements opens up drug treatment to this complex local balancing act.

It is worth noting in this context that local government budgets have been reduced by $40 \%$ in the five years since 2010 (Local Government Association, 2014b) and when combined, drug and alcohol treatment account for almost $30 \%$ of the local authority public health budget (DCLG, 2014). The connection between these two facts has not gone unnoticed by local authorities, with the Local Government Association (2014a) using a press release on 'legal highs' - discussed in the next section - to note:

Councils spend about 30 per cent ( $£ 830$ million a year) of their entire public health budget on drug and alcohol misuse - more than any other service. They argue this clamp-down [on new psychoactive substances] would help reduce this staggering sum - so funds could be freed up for other health priorities.

I do not wish to question or affirm the wisdom of this approach here, but simply to highlight that the responses to this situation will be determined by local elected members and officers through internal council decision-making processes and broader partnership meetings such as Health and Wellbeing Boards.

\section{Supply: the case of new psychoactive substances}

Patterns of substance use in the UK and more widely have been affected in recent years by the phenomenon of new psychoactive substances (NPS), more commonly referred to as 'legal highs' (Measham et al., 2010). NPS produce effects similar to illicit substances but are (initially at least) not subject to the same controls as they are not specifically named within relevant regulations. The very phrase 'legal high' draws attention to the fact that their being legal marks them out from other psychoactives, underscoring the difficulties faced by drug policy in relation to these substances. 
There are no doubt macro-level influences behind the emergence of these substances. The particular prominence of mephedrone at a particular time, for example, was the result of a combination of factors. Power (2013) has noted how the internet disrupted established supply chains, making other forms of supply and delivery possible. McElrath and Van Hout (2011: 494) have noted that the quality of more traditional drugs of misuse such as cocaine was poor at that moment, making mephedrone more attractive. While such a drop in quality might be simply an issue with those established supply routes, Sumnall et al (2011) have noted that this can be seen as a consequence of prohibitionist policies. These policies are framed at national and international levels, and so it could be argued that such an analytic perspective is just as valuable for new psychoactive substances as much as other drugs.

At the same time, the way in which the range of influencing factors are played out and affect the end user will vary by location, with local policymakers a key influence on this. Sumnall et al (2011) note that there are three routes for acquiring new psychoactive substances: direct via the internet, from street dealers, or through high street 'head shops'. Sumnall et al play down the relevance of street dealers (and in any case these are unlikely to produce a different dynamic from that surrounding illicit substances) while the internet supply route is not dependent on local factors. However, the final of these three routes has a distinct local dimension. The freedom with which 'head shops' can operate is largely in the hands of local policy. The Home Office (2013) has released guidance for local authorities on how to approach the issue, but there is still considerable local autonomy and the level of commitment has varied across the country. Activity by local police and trading standards teams in Kent to target multiple head shop outlets has attracted widespread attention, which only serves to illustrate how this locality has felt the need - and been able - to take a distinctive approach. Indeed the Local Government Association (2014a) has described the action taken in Kent as 'unique'. The approach to regulation, therefore, is quite clearly not made by the Home Office, which can only offer 'guidance'.

At the time of writing, the Psychoactive Substances Bill, introduced by the newly-elected Conservative government, is in the committee stage of the House of Lords. This may change the legal status of various substances, and reduce local autonomy, but its final passage and format are as yet unclear. Moreover, there is considerable provision in the bill for local authority activity, for example through the use of prohibition orders (Home Office 2015). An assessment of how the bill, if passed into law, is transformed into local policy and intervention, would be an appropriate subject for research, using the approach detailed in the following section.

\section{The methodological way forward}

The two case studies presented here suggest that key elements of the policy picture are affected by local decisions. This section considers how a critical academic perspective might best be brought to bear upon these decision-making processes.

There are many advantages to this autonomy on offer to local areas. It is unlikely that the same approach should be taken to the regulation and treatment of substance in Camden as Cornwall. However, we should not imagine that these conditions will deliver a straightforward evidence-based approach producing solutions neatly tailored to local needs and circumstances. The academic literature on drug and alcohol policy makes clear the complexity of the policymaking process at a national level, and there is no reason to imagine local policymaking will be any less complex. 
The aim of research into policymaking, whether at a local or national level, is to identify and investigate the factors that shape the experience of end users - of substance and/or services. This calls to mind Michael Lipsky's (2010) notion of 'street level bureaucracy', conveying his understanding that policy in its final form is 'made' by local civil servants and practitioners on the ground through their interactions with the wider public. However, such an approach still maintains if not a hierarchy then a chronology of policy implementation: it is made at national level and filters down through local authorities to practitioners and then the 'street'. It is my contention here that we need a research methodology with the town hall at its centre, rather than either Whitehall or the 'street'.

There are several models of policymaking analysis applicable to this task, and already adapted for the study of alcohol and drug policy specifically. Katikireddi et al (2014) bring together the insights of three models to better understand the formation of MUP in Scotland: 'multiple streams', 'punctuated equilibrium' and 'multi-level governance'. Alternatively, established models - such as Kingdon's 'multiple streams' - can be developed, as Nicholls and Greenaway (2015) have recently done, arguing that policy debate is affected by the following categories of issue: definitional; ideological; systemic; and evidential.

Such models then need data to assess their applicability. Nicholls and Greenaway (2015) draw on qualitative interview data, as do Katikireddi et al (2014), and the work of the same team on newsprint coverage also helps illuminate the more public aspect of policymaking (Hilton et al., 2014). This combination of interview data and publicly available policy, media and historical documents was used in what is possibly the clearest example of an analysis of local policymaking in relation to alcohol or drugs: the history of alcohol policy in Nottingham written by McGregor and Berridge (2011).

Such work can illuminate well several of the categories outlined by Nicholls and Greenaway. The definition of a problem - intoxication or harm, for example - can plausibly be identified through documents and interviews, as can the ideology circumscribing proposed solutions. To take an example from my own work, it could be argued on the basis of public statements that English alcohol policy is shaped by discomfort with the carnivalesque, within a neoliberal framework of action (Haydock 2015).

However, while documentary research is useful in considering the overall definitional and ideological framework underlying a policy, it cannot tell us the detail of how decisions were reached - the mechanics of the bureaucracy and its 'thought style' (Nicholls and Greenaway, 2015: 5). Interview data can bring us a step closer to the decision-making process, but it is important to remember that such occasions are interactions within a particular setting, where accounts will be constructed for the audience, potentially telling us more about how the interviewee wishes to present themselves than anything else (Silverman, 2003).

Therefore, there is a key value in observational data. Alex Stevens' (2011) ethnographic account of work within a policymaking team in Whitehall is instructive in this respect, with its insight into how briefings were written and what was considered evidence for a policy. The ethnographic method is founded on participation and observation within a setting, allowing insights into how those briefings are put together and how decision-making committees operate in practice. 
It was noted above that a public health approach to drug treatment could differ to that of the NTA. Using the framework provided by Nicholls and Greenaway, this difference could be understood as 'definitional' - that is, the issue is in the definition of the problem as located either at a population level or sub-group. However, there may also be systemic and evidential differences. That is, the decision-making systems of local authorities may produce different outcomes, and the definition of 'evidence' might vary. Shortly after the transition, for example, public health professionals reported concern that decisions are taken not on the basis of evidence, but politics and process (Royal Society for Public Health, 2014). An ethnographic approach could offer insights into these politics and processes.

\section{Conclusion}

This article should not be read as a claim that there is little work on policymaking within local authorities; there are whole journals dedicated to such topics. Neither should it be seen as asserting that there is little work on alcohol or drug policy that is locally-specific; the field of alcohol and drug history is again replete with examples. Rather, I make two limited claims. First, while there is considerable - and expanding - work on the policymaking process in relation to drugs and alcohol at a national level, there is less on this how process operates at a local level, though there is some notable work on the effects of such policy. Second, given the governance in relation to drugs and alcohol in place within the UK today, the relevance of locally-based, ethnographic research into policymaking would be particularly striking. This is not to say that national and international settings are unimportant - indeed the relevance of new psychoactive substances as a policy 'problem' is the result of such wider influences. However, the policies that shape individuals' experiences of substance use are unavoidably - and perhaps increasingly - local.

There are of course limitations in the analysis and argument presented here. First, I have not considered the role of locality in shaping preventive policy, at a moment when it could be argued that central control is increasing in the UK - a point at odds with the broad brush picture painted by this brief article. On the other hand, locally-based research could only serve to highlight such potential inconsistencies, rather than obscuring them.

Perhaps of more relevance, therefore, is the focus of this paper on the UK, and indeed England specifically. A defence of this focus could be mounted by observing that, as noted in the introduction, it is not only in the UK that substance use policy is operating at a sub-national level; in the USA states are taking divergent positions on the regulation of marijuana, for example.

Nevertheless, this is only one (quite different) development and the specific arguments made here regarding the importance of research into local policymaking may be of limited relevance to wider settings.

Nevertheless, the relevance of these claims to the UK at least is clear. As noted above, Robin Room (2004) was concerned a decade ago that the Labour government 'intended to eviscerate any possibility of effective action on alcohol issues at the local level'. The concern for UK policy commentators today may be somewhat different, with local policy being the only option for those seeking to implement policies to reduce alcohol harm.

To take the most striking example, minimum unit pricing (MUP) of alcohol has been effectively rejected by the government (Browne, 2013), despite being described by one campaigning 
organisation as 'probably the single most effective measure the Government could take to reduce alcohol morbidity and mortality' (Institute of Alcohol Studies, 2013). There is no suggestion this situation would change after the 2015 General Election, as the Labour Party makes no mention of the initiative is its 2015 public health policy document, preferring to focus on the specific product of strong cider (Labour Party, 2015).

Despite the possibility of local pricing arrangements (Pendlebury, 2009), MUP is very much a policy in the hands of national government, and in its place local initiatives reign supreme. As it announced its rejection of MUP, the Coalition stated that rather than introducing MUP it would 'facilitate local action', while the Labour Party promised to make public health a licensing objective, which would increase the autonomy and role of local authorities in relation to alcohol policy. This emphasis on the local has particular resonance when it is noted that the Portman Group - which represents UK drinks producers - has recently taken to emphasising the need for local solutions rather than national 'red tape' (Gander, 2015; Hopkins, 2015).

Whether the current balance between local autonomy and national control is felt to be appropriate or not, there is value in research to consider how local policy is made, and the relevance of this work seems only likely to increase. Armed with the findings of such work, policy commentators can feel confident not only in stating the current position, but also in suggesting constructive potential ways forward to develop this policymaking environment. I hope this paper can be seen as a contribution to this ongoing process.

\section{References}

Berridge, V. (2013), Demons: Our changing attitudes to alcohol, tobacco, \& drugs, Oxford, OUP. Browne, J. (2013), Government's response to the alcohol strategy consultation, available at: https://www.gov.uk/government/speeches/governments-response-to-the-alcohol-strategyconsultation (accessed 12 August 2013).

DCLG (2014), Local Authority Revenue Expenditure and Financing: 2014-15 Budget, England (revised), available at:

https://www.gov.uk/government/uploads/system/uploads/attachment_data/file/365581/R A_Budget_2014-15_Statistical_Release.pdf (accessed 21 February 2015).

Duke, K. (2013), "From Crime to Recovery: The Reframing of British Drug Policy?" Journal of Drug Issues Vol 43 Issue 1, pp.39-55.

Faculty of Public Health (2010), "What is Public Health?" Available at: http://www.fph.org.uk/what_is_public_health (accessed 27 August 2013).

Gander, K. (2015), "Binge drinking in decline among young adults", The Independent, 16 February, available at: http://www.independent.co.uk/life-style/health-and-families/healthnews/binge-drinking-in-decline-among-young-adults-10045870.html (accessed 22 February 2015).

Green, J. (2014), "What kind of research does public health need?" Critical Public Health Vol 24 Issue 3, pp.249-252.

Greenaway, J. (2003), Drink and British Politics since 1830: A study in policy-making. Basingstoke,Palgrave Macmillan.

Haydock, W. (2015) "Understanding English alcohol policy as a neoliberal condemnation of the carnivalesque", Drugs: Education, Prevention and Policy Vol 22 Issue 2, pp.143-149.

Hilton, S., Wood, K., Patterson, C., Katikireddi, S.V. (2014), "Implications for alcohol minimum unit pricing advocacy: What can we learn for public health from UK newsprint coverage of key claim-makers in the policy debate?" Social Science \& Medicine Vol 102, pp.157-164. 
HM Government (2010), Drug Strategy 2010. Reducing Demand, Restricting Supply, Building Recovery: Supporting People to Live a Drug Free Life, available at: https://www.gov.uk/government/uploads/system/uploads/attachment_data/file/118336/d rug-strategy-2010.pdf (accessed 31 January 2015).

HM Government (2012), The Government's Alcohol Strategy, London, The Stationery Office.

Holder, H.D., Reynolds, R.I. (1997), "Application of local policy to prevent alcohol problems: experiences from a community trial", Addiction Vol 92 Issue 6s1, pp.285-292.

Holmila, M., Warpenius, K. (2007), "A study on effectiveness of local alcohol policy: Challenges and solutions in the PAKKA project" Drugs: Education, Prevention, and Policy Vol 14 Issue 6, pp.529-541.

Home Office (2013), Guidance for local authorities on taking action against 'head shops' selling new psychoactive substances (NPS), available at:

https://www.gov.uk/government/uploads/system/uploads/attachment_data/file/264887/T aking_action_against_head_shops.pdf (accessed 21 February 2015).

Home Office (2015) Psychoactive Substances Bill [HL] 2015-16, available at http://services.parliament.uk/bills/2015-16/psychoactivesubstances.html (accessed 30 June 2015)

Hopkins, A. (2015), "Portman Hits Out At Labour Public Health Plan", The Spirits Business, 16 January, available at: http://www.thespiritsbusiness.com/2015/01/portman-hits-out-atlabour-public-health-plan/ (accessed 22 February 2015).

House of Commons Education Committee (2015), Life Lessons: PSHE and SRE in schools, London, The Stationery Office, available at: http://www.publications.parliament.uk/pa/cm201415/cmselect/cmeduc/145/145.pdf (accessed 21 February 2015).

Humphreys, D.K. , Eisner, M.P. (2010), "Evaluating a natural experiment in alcohol policy", Criminology \& Public Policy Vol 9 Issue 1, pp.41-67.

Institute of Alcohol Studies (2013), "Government U-Turn on Minimum Unit Pricing of Alcohol in England", available at: http://www.ias.org.uk/What-we-do/Publication-archive/TheGlobe/Issue-3-2013/Government-U-Turn-on-Minimum-Unit-Pricing-of-Alcohol-inEngland.aspx (accessed 22 February 2015).

Katikireddi, S.V., Hilton, S., Bonell, C., Bond, L. (2014), “Understanding the Development of Minimum Unit Pricing of Alcohol in Scotland: A Qualitative Study of the Policy Process", PLOS ONE Vol 9 Issue 3: e91185.

Labour Party (2015), Protecting Children, Empowering All: Labour's New Approach to Public Health in the 21st Century, available at:

http://www.yourbritain.org.uk/uploads/editor/files/Public_Health.pdf (accessed 22 February 2015).

Lee, J. (2014), "Which states have legalized medical marijuana?" USA Today, 6 January, available at: http://www.usatoday.com/story/news/nation-now/2014/01/06/marijuana-legal-statesmedical-recreational/4343199/ (accessed 21 February 2015).

Lipsky, M. (2010), Street Level Bureaucracy: dilemmas of the individual in public services. New York, Russell Sage Foundation.

Local Government Association (2014a), "Government urged by councils to outlaw all 'legal high' sales", available at: http://www.local.gov.uk/media-releases//journal_content/56/10180/6516886/NEWS (accessed 21 February 2015).

Local Government Association (2014b), Local Government Association briefing: Provisional Local Government Finance Settlement 2015-16, available at: http://www.local.gov.uk/documents/10180/5533246/LGA+On+the+Day+briefing+Provisiona I+LG+Finance+Settlement-201516.pdf/4ce0905f-d881-4426-8a7b-9755ec6d26bc (accessed 21 February 2015). 
MacGregor, S. (ed) (2014), Local and National Alcohol Policy: How do they interact? Available at: http://blogs.Ishtm.ac.uk/history/files/2015/01/Alcohol_seminar_report_December_2014.pd $f$ (accessed 21 February 2015).

Maclennan, B., Kypri, K., Room, R., Langley, J. (2013), "Local government alcohol policy development: case studies in three New Zealand communities", Addiction Vol 108 Issue 5, pp.885-895.

Mahon, L., Nicholls, J. (2014), Using licensing to protect public health: From evidence to practice, London, Alcohol Research UK, available at:

http://alcoholresearchuk.org/downloads/finalReports/FinalReport_0114.pdf (accessed 24 August 2014).

Mawby, R.I. (2012), "Public disorder, antisocial behaviour and alcohol-related crime: from the metropolis to the tourist resort", In: Jones C, Barclay E and Mawby RI (eds) The Problem of Pleasure: Leisure, tourism and crime. London: Routledge, pp.93-107.

McElrath, K., Van Hout, M.C. (2011), "A Preference for Mephedrone: Drug Markets, Drugs of Choice, and the Emerging "Legal High" Scene", Journal of Drug Issues Vol 41 Issue 4, pp.487-507.

McGregor, J., Berridge, V. (2011), "Local and National Policy Making for Alcohol: Nottingham, UK, 1950-2007", Social History of Alcohol and Drugs Vol 25, pp.148-164.

Measham, F., Moore, K., Newcombe, R., Welch, Z. (2010), "Tweaking, bombing, dabbing and stockpiling: the emergence of mephedrone and the perversity of prohibition", Drugs and Alcohol Today, Vol 10 Issue 1, pp.14-21.

National Treatment Agency (2012), Why Invest? How drug treatment and recovery services work for individuals, communities and societies, available at: http://www.nta.nhs.uk/uploads/whyinvest2final.pdf (accessed 19 February 2015).

National Treatment Agency (2013), "Funding for drug and alcohol prevention, treatment and recovery services", available at: http://www.nta.nhs.uk/funding.aspx (accessed 18 February 2015).

Nicholls, J. (2009), The politics of alcohol: A history of the drink question in England, Manchester, Manchester University Press.

Nicholls, J., Greenaway, J. (2015), "What is the problem?: Evidence, politics and alcohol policy in England and Wales, 2010-2014", Drugs: Education, Prevention, and Policy, Early online.

Pendlebury, F. (2009), "99p pint sees end to Bournemouth town centre agreement", Daily Echo, 8th January, available at:

http://www.bournemouthecho.co.uk/news/4030518.99p_pint_sees_end_to_bournemouth _town_centre_agreement/ (accessed 9th January 2009).

Phillips, G., Green, J. (2015), "Working for the public health: politics, localism and epistemologies of practice", Sociology of Health \& Illness Early Online.

Power, M. (2013), Drugs 2.0: The web revolution that's changing how the world gets high, London, Portobello.

Room, R. (2004), "Disabling the public interest: alcohol strategies and policies for England", Addiction Vol 99 Issue 9, pp.1083-1089.

Royal Society for Public Health (2014), The views of public health teams working in local authorities, available at:

http://www.rsph.org.uk/filemanager/root/site_assets/about_us/reports_and_publications/t he_views_of_public_health_teams_working_in_local_authorities.pdf (accessed 22 February 2015).

Shapiro, H. (2013), "Druglink Interview: Paul Hayes", Druglink, January / February, pp.8-11, available at:

http://www.drugscope.org.uk/Resources/Drugscope/Documents/PDF/Publications/PaulHay esInterview.pdf (accessed 18 February 2015).

Silverman, D. (2003), "Analyzing Talk and Text", In: Denzin, N.K. and Lincoln, Y.S. (eds) Collecting and Interpreting Qualitative Materials, London, Sage, pp.340-362. 
Stevens, A. (2011), "Telling Policy Stories: An Ethnographic Study of the Use of Evidence in Policymaking in the UK", Journal of Social Policy Vol 40 Issue 2, pp.237-255.

Sumnall, H.R., Evans-Brown, M., McVeigh, J. (2011), "Social, policy, and public health perspectives on new psychoactive substances", Drug Test Anal Vol 3, Issue 7-8, pp.515-523.

The Herald (2014), "Legal challenge against minimum alcohol pricing in Scotland referred to European court", The Herald, 30 April, available at:

http://www.heraldscotland.com/news/home-news/legal-challenge-against-minimumalcohol-pricing-in-scotland-referred-to-european-cour.1398862045 (accessed 21 February 2015).

Thom, B. (1999), Dealing with Drink, London, Free Association Books.

United Nations (1988), United Nations Convention Against Illicit Traffic in Narcotic Drugs and Psychotropic Substances, 1988, available at:

https://www.unodc.org/pdf/convention_1988_en.pdf (accessed 21 February 2015).

Yeomans, H. (2014), Alcohol and moral regulation: Public attitudes, spirited measures and Victorian hangovers, Bristol, Policy Press. 